Tersedia online di http://ejournal-balitbang.kkp.go.id/index.php/jp
e-mail:jurnalpari@gmail.com
Jurnal Pari
Volume 2 Nomor 1 Juli 2016
p-ISSN : 2502-0730
e-ISSN : 2549-0133

\title{
PENGEMBANGAN KOLEKSI PADA PERPUSTAKAAN PUSAT PENELITIAN DAN PENGEMBANGAN PERIKANAN
}

\section{COLLECTION DEVELOPMENT ON LIBRARY OF RESEARCH CENTER AND FISHERIES DEVELOPMENT}

\author{
Arief Gunawan, Darwanto dan Nazrul Rizal A. Lubis \\ Pusat Penelitian dan Pengembangan Perikanan \\ Diterima tanggal : 6 Mei 2016 Diterima setelah perbaikan : 20 Juni 2016 \\ disetujui terbit : 8 Juli 2016
}

\begin{abstract}
ABSTRAK
Pengembangan koleksi terdiri dari kegiatan analisis pengguna (community analysis), kebijakan pengembangan, seleksi, akuisisi/pengadaan, penyiangan (weeding),dan evaluasi. Kegiatan pengembangan koleksi pada Perpustakaan Pusat Penelitian dan Pengembangan Perikanan sudah dilaksanakan tetapi belum maksimal sesuai dengan standarisasi yang ada. Koleksi yang ada saat ini terdiri dari pembelian, terbitan sendiri, hadiah dan hibah dari peneliti dan pejabat yang ada dilingkungan perpustakaan serta mengunduh jurnal-jurnal internasional melalui situs science direct. Pengadaannya bersifat kurang aktif. kendala yang dihadapi adalah: tidak adanya dana pasti yang dikhususkan untuk pembelian buku, kurangnya fasilitas perpustakaan seperti komputer, scanner, belum dilakukannya promosi secara terbuka dan bersifat online ke internet
\end{abstract}

Kata Kunci : Koleksi, Perpustakaan, P4

\section{ABSTRACT}

The development of collection consists of a user activity analysis (community analysis), policy development, selection, acquisition/procurement, weeding and evaluation. Library collection development activities of the Fisheries Research and Development Center has been implemented but not maximized in accordance with the existing standardization. The collections currently consist of the purchased, selfpublished, gifts and grants of researchers and authorities within the environment of the library and downloaded copies of international journals through sciencedirect.com site. Procurement is less active. Problem encountered are : lack of funds devoted to the purchase of books, lack of library facilities such as computers , scanners, has not done openly and promotion is online to the Internet .

Keywords : collection, library, P4

Korespondensi Penulis :

Gedung Balitbang II, JI. Pasir Putih II, Ancol Timur, Jakarta Utara 14430

Email : arief_goen@yahoo.com 


\section{PENDAHULUAN}

Perpustakaan Pusat Penelitian dan Pengembangan Perikanan (P4) merupakan perpustakaan khusus yang bergerak dalam bidang kelautan dan perikanan yang bernaung dibawah Kementerian Kelautan dan Perikanan.

Perpustakaan menurut UU No 43 Tahun 2007 adalah sebuah institusi pengelola koleksi karya tulis, karya cetak, dan/atau karya rekam secara professional dengan system yang baku guna memenuhi kebutuhan pendidikan, penelitian, pelestarian, informasi dan rekreasi bagi pemustaka. Perpustakaan sendiri bertujuan memberikan layanan kepada pemustaka, meningkatkan kegemaran membaca, serta memperluas wawasan dan pengetahuan untuk mencerdaskan kehidupan bangsa.

Perpustakaan khusus adalah perpustakaan yang diperuntukkan secara terbatas bagi pemustaka di lingkungan lembaga pemerintah, lembaga masyarakat, lembaga pendidikan keagamaan, rumah ibadah, atau organisasi lain. (UU No. 43 Tahun 2007)

Pengembangan koleksi merupakan kegiatan untuk menghasilkan bahan pustaka baru di perpustakaan berdasarkan hasil seleksi dan evaluasi bahan pustaka serta menampung permintaan dari para peneliti untuk menunjang teori-teori yang diperlukan. Kegiatan pengembangan ini melibatkan staf perpustakaan, para profesor, para peneliti, pemustaka/pengguna perpustakaan. Staf perpustakaan sebagai pihak yang lebih aktif untuk membuat rancangan pengadaan yang tepat, karena menghimpun hasil dari rancangan pengadaan yang dibuat atas permintaan pengguna perpustakaan serta koleksi paling banyak dibutuhkan serta masukan dari para peneliti sebagai pengguna perpustakaan pada umumnya. Perpustakaan P4 dalam mengembangkan koleksinya selama ini dengan pembelian, sumbangan, penggandaan, hibah dan hadiah.
Fungsi Pengembangan Koleksi adalah sebagai berikut : (1) Meningkatkan kuantitas koleksi perpustakaan, agar koleksi berkembang serta seimbang dalam varian subjek, jenis dan bentuk, serta formatnya dalam rangka mencukupi kebutuhan informasi bagi pemustaka atau pemakainya; (2) Meningkatkan kualitas koleksi perpustakaan baik segi ketepatan subjek, kebaruan kandungan informasinya serta kesesuaian dengan kebutuhan informasi pemakainya; (3) Menjamin agar koleksi perpustakaan senantiasa up to date sehingga tetap diminati pemustaka atau pemakainya. Perpustakaan berfungsi sebagai wahana pendidikan, penelitian, pelestarian, informasi dan rekreasi untuk meningkatkan kecerdasan dan keberdayaan bangsa.

Tujuan perpustakaan memberikan layanan kepada pemustaka, meningkatkan kegemaran membaca, serta memperluas wawasan dan pengetahuan untuk mencerdaskan kehidupan bangsa.

Koleksi perpustakaan adalah semua informasi dalam bentuk karya tulis, karya cetak, dan/atau karya rekam dalam berbagai media yang mempunyai nilai pendidikan, yang dihimpun, diolah dan dilayankan. (UU No. 43 Tahun 2007). Koleksi perpustkaan diseleksi, diolah, disimpan, dilayangkan, dan dikembangkan sesuai dengan kepentingan pemustaka dengan memperhatikan perkembangan teknologi informasi dan komunikasi, pengembangan koleksi perpustakaan dilakukan sesuai dengan standar nasional perpustakaan.

\section{TINJAUAN PUSTAKA}

Pengembangan Koleksi menurut Standar Nasional Perpustakaan (SNP 006:2011) :

a) Perpustakaan mempunyai kebijakan pengembangan koleksi.

b) Penambahan koleksi buku sekurangkurangnya $5 \%$ dari jumlah judul per tahun 


\section{Pengembangan Koleksi}

\section{Pengertian Pengembangan Koleksi}

Pengembangan bahan koleksi perpustakaan (Library Collection development) merupakan upaya untuk meningkatkan kualitas layanan perpustakaan melalui penyediaan bahan perpustakaan yang mencukupi dan sesuai dengan kebutuhan pemustaka. Perpustakaan merupakan suatu peran penengah (intermediary) yang mempertemukan antara kebutuhan pemakai dengan koleksi yang tersedia di perpustakaan. Artinya perpustakaan adalah suatu lembaga yang mempertemukan antara dua pemustaka, yaitu sebagai pencari informasi dengan penulis informasi melalui karya yang ditulisnya. Sesungguhnya Perpustakaan harus mampu menyimpan khazanah budaya bangsa atau masyarakat tempat perpustakaan berada dan juga meningkatkan nilai dan apresiasi budaya masyarakat sekitar melalui proses penyediaan bahan Bacaan (Wiji Suwarno :2007 ; 15).

Koleksi yang baik hanya berasal dari pemilihan bahan perpustakaan yang baik pula. Untuk itu diperlukan kebijakan yang memandu pengembangan koleksi. Dengan kebijakan pengembangan koleksi, yang secara resmi disahkan oleh pimpinan lembaga ybs, perpustakaan memiliki pegangan untuk mengembangkan koleksinya. Selain itu, perpustakaan juga akan memiliki kekuatan resmi untu menjalin hubungan dengan berbagai pihak, baik di dalam maupun diluar lembaganya. Pengembangan koleksi haruslah selalu didasari asas tertentu, yang harus dipegang teguh. Untuk perpustakaan perguruan tinggi misalnya, perpustakaan harus menjaga agar koleksinya berimbang sehingga mampu memenuhi kebutuhan dosen, mahasiswa dan peneliti. Demikian pula kebutuhan kurikulum perlu diperhatikan. Sebab itu asas pengembangan koleksi perlu diperhatikan dalam memilih bahan perpustakaan, antara lain kerelevanan, berorientasi kepada kebutuhan pengguna, kelengkapan, kemutakhiran dan kerjasama.
Pengembangan koleksi adalah suatu istilah yang digunakan secara luas di dunia perpustakaan untuk menyatakan bahan pustaka apa saja yang harus diadakan di perpustakaan. Sebelumnya muncul istilah seleksi buku, buku dalam pengertian yang lebih luas yang mencakup monografi, majalah, bahan mikro dan jenis bahan pustaka lainnya. Menurut $A L A$ Glossary of Library and Information Science (1983). Pengertian Pengembangan koleksi adalah:

Pengembangan koleksi meliputi kegiatan memilih dan mengadakan bahan perpustakaan sesuai dengan kebijakan yang ditetapkan oleh pustakawan bersama-saman dengan pengguna perpustakaan, peneliti, professor, kakelti, kepala pusat P4. Pengembangan koleksi didasari asas berikut diantaranya :

1. Kerelevanan :

Koleksi hendaknya relevan dengan penelitian, baik penelitian laut maupun penelitian umum daratan, berguna bagi masyarakat, pengusaha dibidang perikanan, para professor, tenaga ahli. Dilihat pula dari jenjang pendidikan yang ada (S1, S2, S3).

2. Berorientasi pada Kebutuhan Pengguna Pengembangan koleksi harus ditunjukan pada pemenuhan kebutuhan pengguna. Pengguna perpustakaan P4 adalah, peneliti, para profesor, Tenaga Ahli di bidang perikanan, staf/karyawan kantor dan mahasiswa.

3. Kelengkapan

Koleksi hendaknya jangan hanya terdiri atas buku saja melainkan dilengkapi juga dengan majalah, jurnal nasional dan internasional, prosiding, majalah, dan lain-lain

\section{Kemutakhiran}

Koleksi hendaknya mencerminkan kemutakhiran, ini berarti bahwa perpustakaan harus mengadakan dan memperbaharui bahan perpustakaan sesuai dengan perkembangan ilmu pengetahuan terbaru. 
5. Kerja Sama

Koleksi hendaknya hasil kerjasama semua pihak yang berkepentingan dalam pengembangan koleksi, yaitu antara pustakawan, peneliti, profesor, tenaga ahli di bidang kelautan dan perikanan. Dengan kerjasama, diharapkan pengembangan koleksi dapat berdaya guna dan berhasil guna.

\section{Kebijakan Pengembangan Koleksi}

$\begin{array}{clr}\text { Tujuan } & \text { pengembangan koleksi } \\ \text { perpustakaan } & \text { perlu dirumuskan dan }\end{array}$ disesuaikan dengan kebutuhan para peneliti di P4 sehingga dapat terencana mengembangkan koleksinya. Yang perlu dipertimbangkan dalam merumuskan kebijakan pengembangan koleksi, antara lain sebagai berikut :

a) Kebutuhan pengguna perpustakaan

b) Jenis koleksi

c) Kriteria bahan perpustakaan

d) Jumlah eksemplar

e) Bahasa

Sedangkan kewenangan merumuskan kebijakan pengembangan koleksi dipercayakan kepada :

1. Pustakawan dan pengelola perpustakaan

2. Para Peneliti yang akan menggunakan koleksi sebagai sumber informasi

3. Ketua Kakelti sebagai penunjang teori dalam penelitian

4. Para Profesor Peneliti

5. Penanggung jawab kegiatan

Kebijakan pengembangan koleksi Perpustakaan P4 merujuk pada prinsip-prinsip pengembangan koleksi, yaitu sebagai berikut:

1. Relevansi

Koleksi yang ada di perpustakaan P4 sudah relevan ada buku mengenai perikanan laut, perikanan umum daratan, management fisheries, journal fisheries research, marine policy, manajemen perikanan, statistik perikanan dan masih banyak lagi koleksi-koleksi perpustakaan.
2. Kelengkapan

Sampai saat ini koleksi yang ada di perpustakaan tidak hanya buku saja tapi ada bahan pustaka lain seperti, majalah, prosiding, CD, jurnal dalam dan luar negeri, statistik perikanan, peta WPP serta masih banyak lagi.

\section{Kemutakhiran}

Kumutakhiran sumber informasi harus diupayakan sesuai dengan perkembangan ilmu pengetahuan. Kemutahkiran bahan pustaka dapat dilihat dari tahun terbit. Apabila ada terbitan buku atau koleksi baru dengan buku yang menunjang untuk para peneliti, dengan segera harus di adakan agar teori yang mendukung dalam penelitian bias baru dan up to date.

\section{Kerjasama}

Kerjasama ini melibatkan semua komponen dalam pembinaan koleksi, seperti: Kapus, para professor, para peneliti, para staf/karyawan, dan staf perpustakaan di lingkungan P4. Dalam hal ini dapat dilakukan dengan cara tukar-menukar atau silang layang koleksi dengan perpustakaan lain, mengikuti pertemuan-pertemuan, mengikuti pameran, pendidikan dan latihan serta masih banyak lagi kegiatan-kegiatan yang memungkinkan untuk mendapatkan koleksi perpustakaan yang baru.

Qalyubi (2007 : 78-79) menyatakan Kebijakan koleksi tertulis berfungsi :

Menjelaskan cakupan koleksi yang telah ada dan rencana pengembangan

- selanjutnya agar diketahui oleh staff, pemakai dan dewan pembina

- Memberi Diskripsi yang sistematis tentang strategi pengelolaan dan

pengembangan koleksi yang diterapkan di perpustakaan

Menjadi pedoman bagi para pustakawan sehingga ketaatan dalam proses

seleksi dan diseleksi terjamin

Menjadi standard atau tolok ukur untuk menilai sejauh mana sasaran

pengembangan koleksi telah tercapai 
Berfungsi sebagai sumber informasi dan panduan bagi staf yang baru mulai

berpatisipasi dalam pengembangan koleksi

Memperlancar koordinasi antaranggota, staf pengambangan koleksi.

Memperlancar kerjasama antar

perpustakaan

Membantu menjaga kontinuitas, khususnya apabila koleksi besar, serta

menjadi kerangka kerja.

Membantu pustakawan menghadapi pengaduan berkenaan dengan bahan yang telah diseleksi atau ditolak.

Mengurangi pengaruh selektor tertentu

Membantu mempertanggungjawabkan alokasi anggaran

Menjadi sarana komunikasi yang baik dengan masyarakat.

\section{Seleksi}

Menurut Magrill dan Corbin (1989: 1) seleksi merupakan kegiatan untuk mengidentifikasikan rekaman informsi yang akan ditambahkan pada koleksi yang sudah ada di perpustakaan. Proses seleksi merupakan kegiatan yang dilaksanakan sebelum kegiatan pengadaan bahan pustaka. Disamping itu menurut Sulistyo Basuki (1993) dalam buku pengantar ilmu peprustakaan bahwa Seleksi atau pemilihan buku adalah memilih buku untuk suatu perpustakaan. Dalam dunia kepustakawanan, seleksi atau pemilihan buku merupakan kegiatan yang paling penting. Diperpustakaan P4 proses penyeleksian koleksi dilakukan sebelum penulisan di buku induk, apabila koleksi penting dan dibutuhkan untuk menambah kolesi, maka akan di tulis di buku ibduk untuk selanjutnya diproses masuk data di komputer.

\section{Weeding/ Deseleksi (Penyiangan)}

Weeding (penyiangan) bahan pustaka/koleksi merupakan salah satu cara dalam melakukan pengembangan koleksi. Koleksi perpustakaan yang hidup dan berkembang akan selalu bertambah, pada akhirnya banyak buku yang tidak bermanfaat lagi, misalnya karena isinya sudah usang atau sudah ada cetakan (edisi) yang lebih baru. Selain itu penyebabnya adalah tidak selalu diikuti oleh perkembangan ruang atau gedung. Kemampuan ruang atau gedung untuk menampung koleksi selalu terbatas, sehingga pustakawan harus mencari jalan keluar agar pertambahan koleksi selalu dapat ditampung. Salah satu cara yang dapat dilakukan, untuk mengurangi koleksi lama adalah dengan cara mengadakan penyianggan bahan pustaka/koleksi.

Penyiangan koleksi adalah suatu proses seleksi dan penarikan koleksi dari perpustakaan: karena suatu keperluan tertentu, karena tidak bermanfaat lagi bagi pengguna perpustakaan yang bersangkutan, atau terjadi perubahan subjek untuk bahan pustaka yang akan dijadikan koleksi, atau bahkan karena sangat dibutuhkan oleh perpustakaan lain.

Pada umumnya Setiap perpustakaan mengadakan penyiangan minimal satu kali setahun, apabila koleksinya masih sedikit. Untuk perpustakaan besar sebaiknya dilakukan setiap tiga bulan sekali agar beban pekerjaan tidak terlalu berat. Tetapi kewajiban tersebut disesuaikan dengan kebijakan yang ada didalam perpustakaan tersebut

Pengertian weeding menurut kamus istilah perpustakaan dan dokumentasi (Nurhaidi Magetsari,dkk) adalah pengeluaran buku-buku yang dianggap sudah tidak dipakai lagi dari koleksi perpustakaan; penyiangan samar adalah pemindahan buku dari satu bagian ke bagian lain atau dari rak yang satu ke rak yang lain.

Deseleksi/weeding (penyiangan) secara sederhana dipahami sebagai usaha untuk mengeluarkan atau menarik bahan pustaka dari koleksi. Koleksi yang telah ada, diperlukan adanya re-evaluasi secara periodik untuk melihat apakah bahan pustaka masih bernilai bagi pemakai koleksi tersebut.

1. Bahan pustaka yang disiangi, karena alasan sebagai berikut:

a. Bahan pustaka yang out of date.

b. Eksemplar terlalu banyak. 
c. Rusak dan sulit diperbaiki.

d. Ada edisi terbaru.

e. Aturan pemerintah melarang.

2. Tujuan Weeding/Deseleksi (Penyiangan)

Menurut Edward Evans (1997: 383), ada empat tujuan yang akan dicapai mengapa penyiangan dilakukan, antara lain:

a) Memperoleh tambahan tempat (shelf space) untuk koleksi yang baru.

b) Membuat koleksi lebih dapat dimanfaatkan sebagai sumber informasi yang akurat, relevan, up to date, serta menarik.

c) Memberikan kemudahan pada pemakai dalam menggunakan koleksi.

d) Memungkinkan staf perpustakaan mengelola koleksi secara lebih efektif dan efisien.

Perpustakaan P4 kegiatan penyiangan atau weeding pernah dilakukan, dalam pelaksanaanya kegiatan weeding tersebut dilakukan apabila stok of name atau pengecekan terhadap koleksi perpustakaan, yang rutin dilakukan setahun sekali apabila menemukan koleksi yang rusak atau sudah tidak terpakai lagi maka akan memisahkan untuk selanjutnya disimpan di gudang khusus, gunanya suatu saat koleksi yang sudah tidak terpakai itu tiba-tiba ada yang mencari mengenai isi informasi yang ada didalamnya. Sehingga pustakawan dengan mudah akan mengambil koleksi tersebut yang di simpan di gudang.

\section{Selving}

Selving merupakan pemajangan buku/koleksi di rak. Pemajangan dikelompokkan menurut subjek, sesuai dengan nomor klasifikasi yang ada dalam label buku. Hal ini dilakukan untuk mempermudah temu kembali koleksi, saat diperlukan pengguna. Di perpustakaan P4 juga kegiatan selving dilakukan yaitu dengan memajang koleksi dengan terbitan baru, pemajangan koleksi bahan pustaka dilakukan di dekat pintu masuk perpustakaan. Gunanya di simpan disitu adalah apabila pengguna yang akan masuk keperpustakaan sebelum masuk pasti melihat koleksi yang dipajang di kotak pemajangan.

\section{METODE}

\section{Analisis Pengguna}

Analisis pengguna menurut beberapa sumber ialah memberikan informasi yang dibutuhkan untuk perencanaan yang efektif (T. D. Wilson dalam Evan, 2000). dalam rangka melakukan analisis pengguna perpustakaan harus ditentukan oleh beberapa hal dibawah ini

1. siapa yang akan melakukan pengumpulan data?

2. Informasi apakah yang diinginkan oleh pengguna?

3. Bagaimana metodenya untuk menghasilkan informasi yang diinginkan?

4. Bagaimana memanfaatkan data itu?

Koleksi perpustakaan diseleksi, diolah, disimpan, dilayankan, dan dikembangkan sesuai dengan kepentingan pemustakan dengan memperhatikan perkembangan teknologi informasi dan komunikasi sesuai dengan standar nasional perpustakaan.

Perpustakaan hendaknya menggunakan pendekatan System Oreinted Approach (pendekatan berorientasi sistem). (Cranfield:1960). Orientasinya adalah bagaimana perpustakaan digunakan pemakai khususnya peneliti dan pengusaha dibidang perikanan serta masyarakat umum sehingga ada keinginan untuk datang ke perpustakaan.

Dalam hal ini yang menjadi target utama pengguna perpustakaan adalah Peneliti, professor, staf/karyawan, mahasiswa dan pengguna perpustakaan khususnya di bidang kelautan dan perikanan. Sehingga koleksi yang ada bisa disesuaikan dengan kebutuhan penggunanya. 


\section{Penerapan Pengembangan Koleksi di Perpustakaan P4}

Secara garis besar Perpustakaan P4 belum melaksanakan kaidah-kaidah pengembangan koleksi seperti yang dijelaskan, namun paparan berikut dapat menjadi bahan pertimbangan bagi kegiatan pengembangan koleksi berikutnya. Langkah-langkah pelaksanaan pengadaan pembelian buku di perpustakaan bisa dilihat pada gambar 1 .

Untuk koleksi lain didapat dari terbitan sendiri terdiri dari jurnal (tabel 1) dan buku yang

\section{Proses Seleksi}

Seleksi adalah tindakan, cara, atau proses memilih. Menurut (Magrill and Corbin :1989:1) proses seleksi merupakan kegiatan untuk mengindentifikasi rekaman informasi yang akan ditambahkan pada koleksi yang sudah ada.

a. Langkah-langkah:

Pelaksana seleksi mengidentifikasi kebutuhan koleksi dalam hal subjek dan jenis materi yang spesifik Penentuan alokasi dana pengembangan koleksi
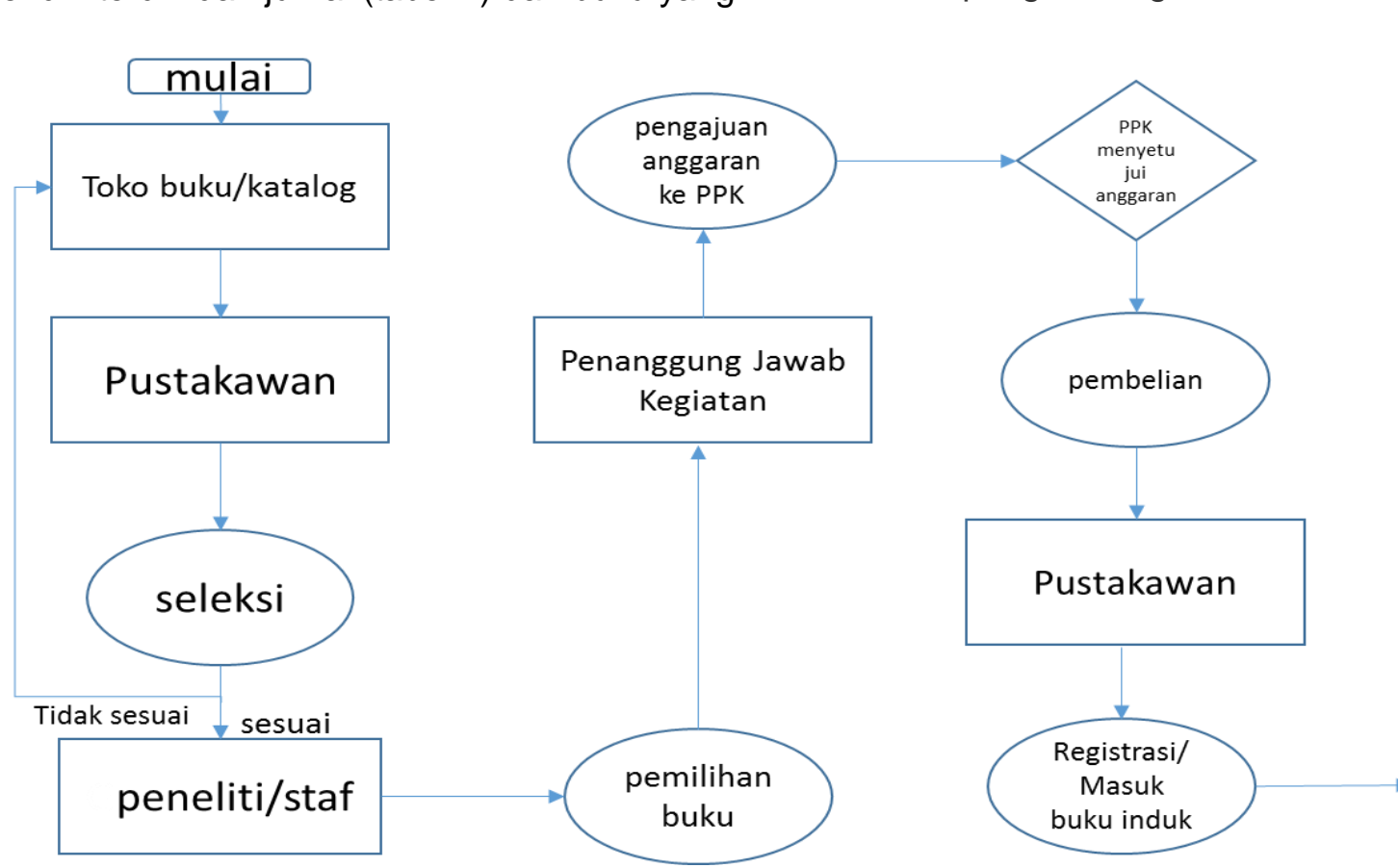

selesai

Gambar 1. Diagram pembelian buku perpustakaan P4

Figure 1. Flowcharts purchase of books in $P 4$

dihasilkan dari kegiatan yang ada di P4, hibah, hadiah, penggandaan buku juga unduhan dari jurnal-jurnal internasional antara lain Fisheries

Penentuan prioritas kebutuhan Research dan Marine Policy dari website sciencedirect.com

Tabel 1. Data Jurnal/Buletin terbitan Pusat penelitian dan Pengembangan Perikanan Table 1. Data Journal / Bulletin published research and Fisheries Development Center

\begin{tabular}{|c|c|c|c|}
\hline No & Nama Jurnal & Volume/tahun & Bulan terbit \\
\hline 1. & $\begin{array}{l}\text { Jurnal Penelitian Perikanan } \\
\text { Indonesia }\end{array}$ & 4 nomor & Maret, Juni, September, Desember \\
\hline 2. & Bawal Widya Riset Perikanan & 3 nomor & April, Agustus, Desember \\
\hline 3. & $\begin{array}{l}\text { Indonesian Fiseheries Research } \\
\text { Journal }\end{array}$ & 2 nomor & Juni, Desember \\
\hline 4. & $\begin{array}{l}\text { Jurnal Kebijakan Perikanan } \\
\text { Indonesia }\end{array}$ & 2 nomor & Mei, Nopember \\
\hline 5. & Buletin Teknis Litkayasa & 2 nomor & Juni, Desember \\
\hline
\end{tabular}


b. Pelaksana Seleksi

Pustakawan

Spesialis subjek

Pimpinan organisasi

Komisi perpustakaan

Anggota lainnya.

\section{c. Kriteria untuk menjadi penangung jawab pemilihan buku yang baik, yaitu :}

1) Mengetahui berbagai jenis bahan pustaka yang ada di pasaran Seorang penyeleksi harus mengenal dan tau tentang koleksi-koleksi apa saja yang sedang diminiati masyarakat.

2) Memahami tujuan dan fungsi perpustakaan

Penyeleksi selain mengetahuai buku yang beredar di pasaran juga harus tahu dan memahami tujuan dan fungsi perpustakaan

3) Mengenal kebutuhan pengguna

Penyeleksi harus mampu mengenal kebutuhan pengguna, buku-buku apa saja yang harus disediakan itu tujuannya adalah agar pengguna puas dengan layanan yang diberikan oleh perpustakaan

4) Mengenal prinsip-prinsip seleksi

Penyeleksi harus mampu dan mengetahui prinsip-prinsip seleksi yang dibagi menjadi 3 pandangan yakni

a. Pandangan tradisional

Prinsip ini mengutamakan nilai interinsik untuk bahan pustaka yang akan di koleksi perpustakaan, yakni titik tolaknya adalah penyeleksi harus mengetahui bahwa perpustakaan adalah tempat untuk melestarikan warisan budaya dan sarana untuk mencerdaskan masyarakat b. Pandangan Liberal

Prinsip seleksi ini pemilihan didasrkan akan prioritas artinya kualitas tetap diperhatikan tetapi dengan lebih mengutamakan pemilihan karena sering dibaca.

c. Pandangan pluralistik

Prinsip yang dianut pandangan ini berusaha mencari keselarasan dan keseimbangan diantara kedua pandangan baik tradisional dan liberal.

5) Mengenal dan mampu menggunakan alat bantu seleksi

Penyeleksi harus mengetahui alat bantu seleksi misalnya katalog penerbit, katalog penerbit ini adalah salah satu alat bantu untuk menentukan buku apa saja yang akan dibeli.

6) Memahami berbagai kendala yang ada Penyeleksi harus mampu mengetahui kendala-kendala apa saja yang dimiliki oleh perpustakaan semisal dana yang dimiliki oleh perpustakaan itu. Sehingga dengan mengetahui kendala itu maka kita bisa mengambil suatu kebijakan sesuai dengan kemampuan itu.

\section{d. Kriteria untuk menjadi pelaksana pemilih buku (selektor) yang baik :}

Menurut (Sulistyo-Basuki : 1991: 42) menyatakan bahwa kreteria untuk menjadi selektor harus memiliki kecakapan sebagai berikut:

1) Menguasai sarana bibliografi yang tersedia, paham akan dunia penerbitan khususnya mengenai penerbit, spesialisasi para penerbit, , kelemahan mereka, standar, hasil terbitan yang ada selama ini dan sebagainya

2) Mengetahui latar belakang para pemakai perpustakaan

3) Memahami kebutuhan pemakai

4) Personel pemilihan bersifat netral, tidak bersifat mendua, menguasai informasi, dan memiliki akal sehat dalam pemilihan buku 
5) Pengetahuan mendalam mengenai koleksi perpustakaan

6) Mengetahui buku melalui proses membukabuka buku ataupun proses membaca.

Selektor juga harus memiliki subjektivitas ketika menjalankan proses seleksi tidak ada keberpihakan terhadap satu pihak, tidak mengutamakan kepentingan sendiri. Menurut (Evans : 1997:121) Seorang penyeleksi harus menjelaskan bahwa falsafah pribadi dapat diwujudkan dengan memhami bagaimana sesungguhnya menjadi selektor yang baik diantaranya adalah seorang selektor bisa menilai secara independen judul-judul tertentu serta membandingkan dengan tinjauan di majalah-majalah yang di temukan

\section{PRINSIP PEMILIHAN}

Mutu dari suatu perpustakaan sangat ditentukan oleh mutu koleksinya, dengan demikian cara pemilihan bahan pustaka yang cermat dan tepat merupakan hal yang penting sekali didalam pengadaan koleksi Menurut (Depag: 2003: 17 ) menyatakan prinsip dan dasar pemilihan adalah menunjang tujuan perpustakaan dan pendidikan.

\section{SUMBER-SUMBER PENGADAAN}

\section{a. Pembelian}

Cara ini adalah salah satu upaya perpustakaan untuk meningkatkan jumlah koleksi namun ini semua tergantung dari anggaran dana yang ada, dana sangat mendukung maka mudah bagi tim seleksi untuk melakukan proses seleksi dan pembelian buku-buku yang dirasa perlu Menurut (Depag: 2003:17) menyatakan bahwa bila perpustakaan menginginkan koleksi tetap segar maka perlu kiranya ada penambahan jumlah jilid setiap tahun tidak bolek kurang dari 5\% dari jumlah jilid seluruh koleksi perpustakaan 9 Untuk itu cara pengadaan dengan pembelian merupakan suatu alternatif bagi perpustakaan untuk menambah koleksi perpustakaan Pembelian bisa dilakukan dengan cara :
1. Membeli langsung ke toko buku.

Dengan membeli di toko buku kita bisa memperkirrakan dana yang perlu dikeluarkan untuk membeli buku-buku yang kita inginkan, biasanya cara-cara seperti ini dilakukan oleh perpustakaanperpustakaan yang memiliki dana minim Menurut (Yulia : 1994:44) menyatakan adapun kemudahan yang diperoleh dengann cara pembelian ke toko buku adalah bahwa kita dapat melakukan efisiensi atau penghematan biaya, waktu dan tenaga

2. Melalui Penerbit

Melakukan pembelian dengan datang atau bekerjasama langsung dengan penerbit memang sangat menguntungkan, karena perpustakaan benar-benar mendapatkan buku dengan harga nett dari penerbit

3. Agen buku

Pembelian dengan bekerjasama dengan agen buku yang disebut pula dengan jobber atau vendor, jobber dan vendor ini adalah perantar antara penerbit dan pembeli yang biasanya untuk pembelian ke luar negeri dan ini banyak dilakukan oleh perpustakaan karena dengan 10 bekerjasama dengan vendor semua kebutuhan akan koleksi sangat mudah didapat

\section{b. Hadiah}

Menurut (FKBA: 2001:35) Ada dua perolehan hadiah yaitu hadiah atas usulan dan hadiah tanpa diminta, hadiah yang diminta sudah melalui proses seleksi sehingga diharapkan sesuai dengan kebutuhan, sedangkan hadiah tanpa diminta sering tidak cocok dengan tujuan perpustakaan penerima sehingga perlu diseleksi lebih jauh untuk dijadikan koleksi perpustakaan

\section{c. Tukar Menukar}

Kegiatan tukar menukar koleksi umumnya dilakukan dengan saling mengirimkan terbitan antar perpustakaan, namun dapat juga dilakukan perpustakaan yang memiliki 
koleksi yang dianggap jumlah exemplarnya berlebih pada setiap judulnya. Unit yang biasanya melakukan proses tukar menukar yakni adalah unit pengadaan, menurut (Yulia: 1994:55) Unit ini juga biasanya ikut serta dalam pemilihan bahan pustaka yang diharapkan dapat diterima dengan melalui pertukaran, melakukan penelusaran bibliografi yang perlu untuk menemukan bahan-bahan pertukaran serta merencanakan dan menorganisasikan pekerjaan-pekerjaan yang berhubungan dengan tukar menukar.

\section{d. Wakaf}

Pengadaan ini biasanya dilakukan oleh perpustakaan pondok pesantren, maupun perpustakaan perguruan tinggi yang basicnya adalah agama, model-nya adalah apabila pemimpin atau kyai memiliki buku 11 koleksi pribadinya banyak maka alternatif yang dilakukan agar bukukoleksi pribadinya tidak menumpuk di ruang kerja/rumah yakni dengan me wakafkan koleksi bukunya kepada perpustakaan-perpustakaan. Banyaknya buku-buku agama (bahkan sudah tidak terbit lagi) yang dimiliki oleh para pendukung pesantren dan para ulama akan memiliki nilai kemanfaatan yang tinggi apabila diwakafkan kepada perpustakaan, di perpustakaan buku itu akan banyak dibaca orang dan pemiliknya masih bisa meminjam buku tersebut. (Depag : 2003: 18) atau menggunakan kartu-kartu dengan bentuk isian yang telah ditentukan. Inventarisasi merupakan suatu kegiatan untuk mencatat pustaka yang menjadi milik perpustakaan, data bibliografis perlu dicatat secukupnya sebagai bahan statistik, evaluasi, dan jawaban kuisioner yang tidak boleh dilupakan disini adalah memberi cap tanda milik perpustakan, karena prosedur awal yang dilakukan oleh pustakawan yang terlibat dalam proses inventarisasi adalah memberi stempel pada buku, baik stempel berkenaan dengan tanda milik perpustakaan, stempel register buku, dan perlengkapanperlengkapan lain seperti lidah buku, label. Pemberian stempel ini di bubuhkan di halamanhalaman yang telah ditentukan sesuai dengan kebijakan perpustakaan itu sendiri.

\section{HASIL DAN PEMBAHASAN}

Pada tabel 2 terlihat bahwa pada tahun 2013-2014 dana pembelian tidak ada dikarenakan ada pemotongan anggaran jadi rencana pembelian buku ditiadakan, untuk tahun 2015 sendiri yang direncanakan pembelian 15 buku hanya terealisasi 7 buah buku. Untuk hibah kita mendapatkan buku dari Bapak (Alm) Achmad Sarnita dan Bapak Purwito Martosubroto. Untuk terbitan sendiri terdiri dari jurnal dan buku hasil kegiatan Pusat Penelitian dan Pengembangan Perikanan seperti terlihat di Tabel 1. Untuk penggandaan kita menggandakan buku-buku yang sudah ada

Tabel 2. Jumlah pengadaan koleksi Pusat Penelitian dan Pengembangan Perikanan Tahun 2013-2015

\begin{tabular}{lcccccc}
\hline Tahun & Pembelian & Hibah & $\begin{array}{c}\text { terbitan } \\
\text { sendiri }\end{array}$ & Penggandaan & Hadiah & Unduh \\
\hline 2013 & & 35 & 25 & 35 & 20 & 467 \\
2014 & & & 25 & 30 & 25 & 20 \\
2015 & 7 & 40 & 13 & 30 & 30 & 19 \\
\hline
\end{tabular}

\section{INVENTARISASI}

Setiap koleksi yang datang perlu dicatat didalam buku inventarisasi sehingga tiap-tiap koleksi memiliki nomer inventarisasi sendiri, pencatatan dapat dilakukan dengan buku folio bergaris yang dipakai dengan kedua sisinya dan buku pinjam dari perpustakaan lain. Untuk hadiah biasa kita dapat dari satuan kerja lain baik dilingkup kementerian kelautan dan perikanan maupun dari luar instansi kementerian. Hasil unduhan kita berupa dua buah jurnal internasional yaitu Fisheries Research dan Marine Policy yang ada 
Tabel 3. Jumlah volume Jurnal Internasional Hasil Unduhan Sciencedirect.com

Table 3. Total volume of International Journal Sciencedirect.com Results Downloads

\begin{tabular}{ccc}
\hline Tahun & $\begin{array}{c}\text { FISHERIES RESEARCH } \\
\text { (Volume/Nomor) }\end{array}$ & MARINE POLICY (Volume/Nomor) \\
\hline s.d. 2013 & 271 & 196 \\
2014 & 12 & 8 \\
2015 & 10 & 9 \\
\hline
\end{tabular}

dalam bentuk softcopy dan hardcopy, hasil jumlah volume terlihat pada Tabel 3.

\section{KESIMPULAN}

Dari penjelasan diatas dapat disimpulkan beberapa hal sebagai berikut:

1. Kegiatan pengembangan koleksi pada Perpustakaan P4 sudah sesuai tetapi belum sempurna dengan kaidah pengembangan koleksi sehingga harus lebih ditingkatkan lagi.

2. pengembangan koleksinya, antara lain jumlah anggaran untuk penambahan dan pemeliharaan koleksi yang tidak pasti, untuk penempatan koleksi juga masih kurang memadai, kurang menunjangnya sarana dan prasarana untuk kerberlangsungan perpustakaan dan pusat informasi.

\section{SARAN}

Dari beberapa permasalahan yang ada di Perpustakaan P4 dapat diuraikan beberapa saran untuk mengatasi masalah-masalah yang ada.

1. hendaknya dilakukan kegiatan-kegiatan: analisis pengguna (user), seleksi bahan pustaka, pengadaan (akuisisi), pengolahan (klasifikasi), penyiangan (weeding), sebagai upaya pengembangan koleksi kedepannya dengan mengundang berbagai sumber dari perpusnas atau orang yang ahli dibidangnya.

2. fasilitas alat untuk penunjang kegiatan perpustakaan sebaiknya dilengkapi

mengingat hal ini sangat penting bagi perpustakaan guna kemajuan perpustakaanya.

\section{DAFTAR PUSTAKA}

"Modul Pengembangan Koleksi". Jakarta: Perpustakaan Nasional RI. http//www.pnri.go.id. diakses oktober 2013.

J,.Alak., PUJP $\quad$ Panduan Perpustakaan

Andriaty. Eda S. Sopia. 2001. Kerjasama Pengguna dan Pustakawan dalam Basuki, Sulistyo. 1991. Pengantar IImu Perpustakaan, Gramedia. Jakarta

Diaz De Santos, S.A. 1983. ALA Glossary Library and Information Science. The American Library Association.

Evans, G. Edward. 1995. Developing Library and Information Centre Collection 3. Colorado: Libraries unlimited.

Forum kajian budaya dan Agama. 2001. Pedoman Pengelolaan Perpustakaan Madrasah. Yogyakarta. BEB

Indonesia, Departemen Agama. 2003. Pedoman Penyelenggaraan Perpustakaan di Pondok pesantren. Jakarta. Ditkekapotren Depag.

Lasa Hs. 2005. "Manajemen Perpustakaan". Yogyakarta: Gama Media.

Lasa Hs. 2007. "Manajemen Perpustakaan Sekolah". Yogyakarta: Pinus Book Publisher.

Magrill, Rose Mary and John Corbin. 1989. Acquistion management Collection Developmentin Libraries. Chicago. American Library Chicago. Nita Ismayanti., 1992. Pemanfaatan layanan perpustakaan; FSUI. Jakarta

Nurhadi, Muljani A. 1983. "Sejarah Perpustakaan dan Perkembangannya di Indonesia". Yogyakarta: Andi Offset 
Rusmana. A. 2002. Analisis Sistem Informasi, Jakarta. Universitas Terbuka menelusur informasi untuk meningkatkan layanan

Sinaga, Dian. 2005. "Perpustakaan Sekolah: Peranannya Dalam Proses Belajarmengajar". Jakarta: Kreasi Media Utama.

Sukaesih, 1998. Pokok Bahasan Layanan Perpustakaan, (Suatu Pengantar /Jurusan IImu Perpustakaan)., Fikom Unpad. Bandung

Sulistyo-Basuki. 1991. Pengantar IImu perpustakaan. Jakarta. Gramedia

Suwardikarta. L.S. 1998. Titik Akses Subyek dalam Organisasi Informasi di Perpustakaan. Terbitan Jurnal IImu Perpustakaan (No. 2) 55 Hal, Jakarta. Fak. Sastra UI.

Trimo, Soejono. 1987. Pedoman Pelaksanaan Perpustakaan, Bandung : Remaja Rosda Karya.

Qalyubi, Syihabudin (et al). 2003. "Dasar-dasar IImu Perpustakaan dan Informasi". Yogyakarta: Jurusan IImu Informasi dan Perpustakaan, Fakultas Adab.

Qalyubi, Syihabuddin. 2007. Dasar-dasar ilmu Perpustakaan dan Informasi. Yogyakarta. Jurusan IImu perustakaan fakultas Adab.

Yulia, Yuyu,. 1994. Pengadaan Bahan Pustaka. Jakarta: Universitas Terbuka 